\title{
Birth and death of oceanic basins: geodynamic processes from rifting to continental collision in Mediterranean and circum-Mediterranean orogens
}

\author{
GEOPROB Project
}

\author{
Guest Editors: G. CAPPONI*†, A. FESTA $\$ \&$ G. REBAY $\S$ \\ *University of Genova, DISTAV, Corso Europa 26, 16132 Genova, Italy \\ $\$$ University of Torino, Earth Sciences Department, Via Valperga Caluso 35, 10125 Torino, Italy \\ ${ }^{\S}$ University of Pavia, Department of Earth Sciences and Environment, Via Ferrata 7, 27100 Pavia, Italy
}

\section{Preface}

The study of the evolution of ocean basins from birth to death is crucial for the understanding of the geodynamic evolution of orogenic systems. Exhumed ophiolite-bearing orogenic belts represent significant fossil analogues of different types of modern oceanic basins, allowing detailed multiscale and multidisciplinary investigations. Such investigations are highly important to our understanding of the ancient and modern geodynamic processes connected to the different stages of complete tectonic evolution, from rifting to subduction, collision and exhumation.

Subduction systems are characterized by huge mass transfers between the subducting lithosphere and the overlying plate, causing the formation of complex lithospheric structures (i.e. subduction complexes, orogenic wedges) made of oceanic and continental slices. An important role in the subduction initiation, evolution and mechanism is played by: (1) the composition and thermal state of the oceanic lithosphere (linked to the rift phases); (2) the reactivation of main shear zones in the passive margin; (3) the type of subducted plate and age of oceanic slab; (4) the convergence rate and its eventual changes, induced by subduction of oceanfloor asperities or by phase transitions in the upper and lower mantle; and (5) the role played by continental collision in driving the exhumation of portions of the subducted slab by channel flow, buoyancy or extrusion, as described by recent conceptual and numerical models.

All of the above lithospheric processes affect the Earth dynamics at different structural levels from the deep-seated part of the subduction system, with related high-pressure metamorphic transformations, fluids and volatile recycling, melting and so on, to the

†Author for correspondence: capponi@dipteris.unige.it shallower parts, with the evolution of accretionary and erosive complexes and the triggering of earthquakes.

The papers published in this Special Issue describe different key sectors of the circum-Mediterranean and Mediterranean Tethys mountain belts, being representative of different stages of geodynamic evolution of oceanic basins associated with two different types of suture (the Alps-Apennines - Maghrebides-Betic belts and the Dinarides-Hellenides belts; Fig. 1) that continue into Turkey and Iran. These orogenic belts differ from each other in terms of occurrence of obduction processes, back-arc basins, different volumes of mélanges and more; in addition, a wide variety of structural levels are exposed in both belts. These papers therefore unravel significant aspects of the opening and closure of oceanic basins, as well as the role played by oceanic-related structural inheritance in controlling processes from subduction to collision and exhumation stages.

We grouped the papers published here by the geodynamic process they discuss, keeping track of their geographical relevance in order to understand the spatial relations among different portions of the complex Mediterranean collisional setting. In addition, some papers go beyond the specific geodynamic process and discuss the regional geodynamics of key areas. The different processes and zones investigated in this Special Issue are rifting, subduction, exhumation, continental collisions, plate interface and accretionary prism dynamics, and regional geodynamics.

\section{Rifting}

Investigations of rifting processes include the study of: the structures linked to the extensional tectonic phases; the thermal anomalies; and the sedimentary and 


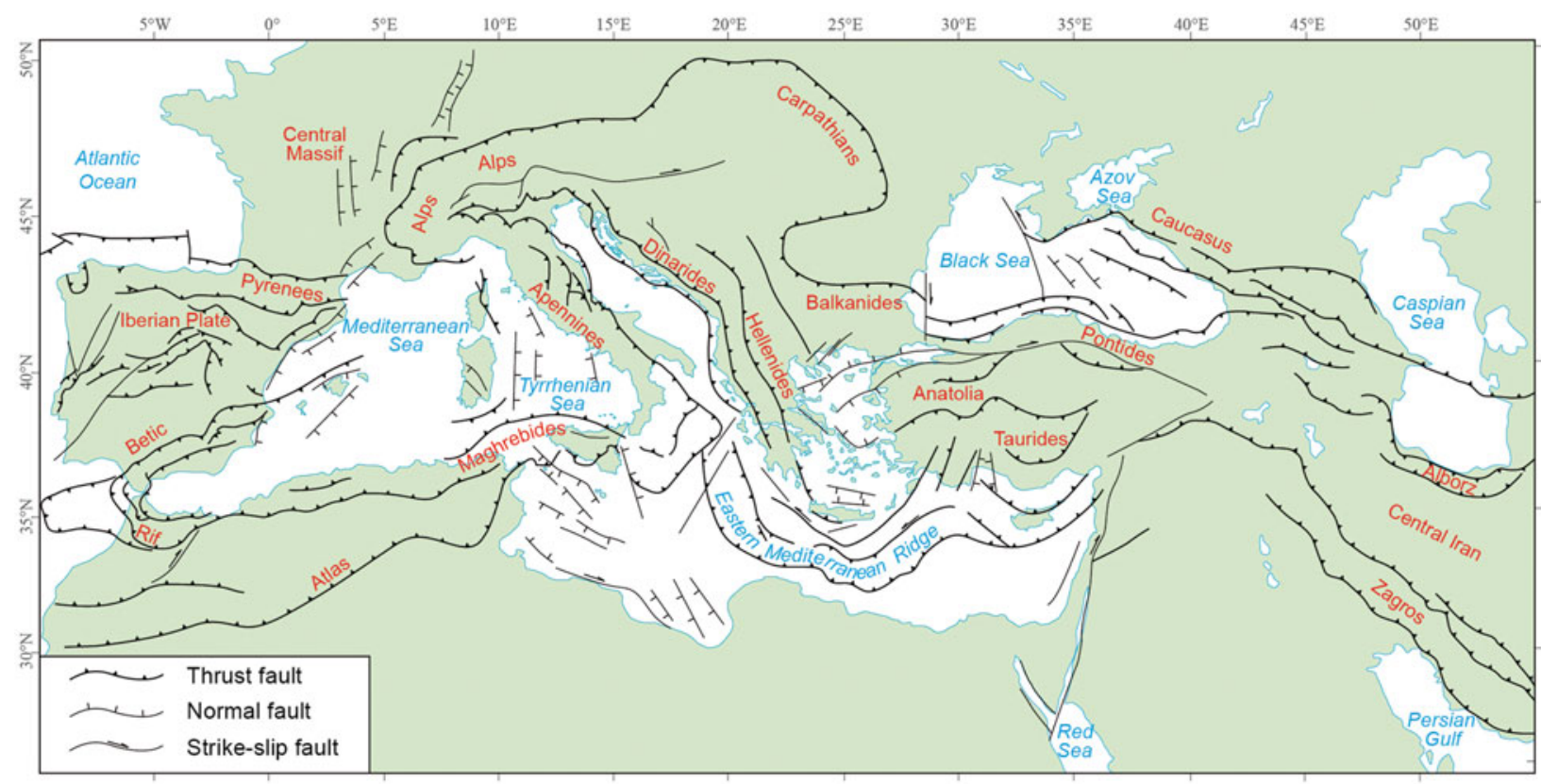

Figure 1. (Colour online) Tectonic map of the Circum-Mediterranean region and Tethys mountain belts (modified from Festa et al. 2016).

magmatic lithological associations, marking the transition from continent to ocean.

The recognition of the structural inheritance of intraoceanic detachment faults formed during Jurassic rifting in the high-pressure Monviso ophiolite in the Western Alps, documented by Balestro et al., is important to understand: (1) the dynamics and characteristics of the extensional processes in the Jurassic Alpine Tethys, which are comparable with those observed in oceanic core complex along the modern slow- and ultraslow-spreading ridges (e.g. MidAtlantic Ridge); and (2) their influence in controlling the subsequent Alpine convergent tectonics from subduction to exhumation stages.

The transition from continental rifting to oceanic spreading is studied by means of numerical modelling by Marotta et al., who develop a two-dimensional thermo-mechanical model considering hydration of mantle during uprising and compare the results with natural data from the Alps and northern Apennines. In this scenario they show that mantle denudation began several million years before the formation of gabbros/basalt, generating an ocean-continent transition (OCT) zone from passive margin to the oceanic lithosphere of size $160-280 \mathrm{~km}$, providing a useful account for the estimation of basin width and rifting time. Their comparative analysis supports the theory that the lithospheric extension preceded the opening of the Alpine Tethys and developed from the recycling of part of the old Variscan collisional suture, rather than beginning from a stable continental lithosphere.

\section{Subduction}

Research into subduction processes involves the study of the evolution of the subducted rocks with their $P-T$ - $t-d$ (pressure-temperature-time-deformation) trajectories, the relationships between deformation and metamorphism, and the numerical modelling of the process.

Scarsi et al. describe the structure and petrology of lawsonite-bearing eclogites from a mélange unit in the Ligurian part of the western Alps, considered as evidence of a complex metamorphic evolution. From their location at the top of the slab interface, at the contact with the mantle slab, it is inferred that these rocks were exhumed in a low-viscosity serpentinite channel in the presence of complex $\mathrm{H}_{2} \mathrm{O}-\mathrm{CO}_{2}$ fluids.

On the other hand, Rebay et al. investigate the timing of high-pressure/ultra-high-pressure (HP/UHP) metamorphism in a portion of the Zermatt-Saas Unit. The authors determine its age of $65 \pm 5 \mathrm{Ma}$, highlighting the problem of the timing and extent of HP/UHP tectonometamorphic units in the ophiolitic zones of the Western Alps. Such results introduce the question of the extent to which the units are undergoing subduction and exhumation in orogenic zones.

Zanchetta et $\boldsymbol{a l}$. analyse the complex and contrasting metamorphic evolution of three blueschist tectonometamorphic units with clockwise and anticlockwise evolutions within the Anarak Metamorphic Complex in Central Iran. All units reached depths of $25 \mathrm{~km}$ within the accretionary wedge, but followed different subduction and exhumation paths.

\section{Exhumation}

Investigations into the exhumation of subducted units include the study of the related metamorphic reequilibrations, deformation mechanisms and numerical modelling.

Malatesta et al. describe the structures and parageneses of a blueschist-facies mylonite in the Voltri 
Massif ophiolite of the western Alps, reconstructing the retrograde metamorphic evolution associated with exhumation. Such evolution is associated with fluid influx at blueschist-facies conditions, with the transition from ductile to brittle deformation. Fluids trapped in the minerals of the mylonite are released during exhumation, possibly through episodic tremors or 'slow earthquakes' triggered by high pore pressure; evidence for the latter is provided by a dense fracture mesh.

Frassi et al. describe the Daday Unit of the Central Pontides (northern Turkey), which consists of a blockin-matrix rock unit derived from supra-subduction oceanic crust and related deep-sea sedimentary cover of Middle Jurassic age. On the basis of different deformation and metamorphic stages, the authors note that the rocks were tectonically underplated at depths up to $42 \mathrm{~km}$ during Late Jurassic time and were exhumed to shallower levels during Albian - late Paleocene time in a continent-arc collision setting.

\section{Continental collision}

Continental collision and its relation to the exhumation and subduction of continental crust is also described in this Special Issue.

Nirta et al. analyse the tectonic unit of the Hellenides in Boetia (central Greece), proposing a new reconstruction of the tectonic evolution of the area and discussing the presence of one or more oceanic basins in its favour. Here, the present-day orogen shows superimposed deformations related to obduction and collision. The ophiolites crop out along different alignments that, on the basis of new data, cannot be interpreted as remnants of different oceanic basins separated by micro-continents; rather, the ophiolites are interpreted as the result of late transposition of relics of a single ocean.

Catalano et al. (a) discuss the effects of a MesoAlpine collision on Variscan basement rocks from Peloritani Mountains, eastern Sicily, where an Alpine metamorphic imprint on basement and cover rocks suggest syncollisional exhumation from Early Cretaceous high-pressure/low-temperature conditions up to shallower levels until $28 \mathrm{Ma}$; later rapid uplift exposed deep-seated crustal levels to the surface.

\section{Plate interface and accretionary prism dynamics}

The dynamics of plate interfaces and the accretionary prism, with comparison between modern prisms and fossil analogues, are discussed in two articles.

Mittempergher et al. describe in detail the internal architecture and deformation mechanisms of the basal thrust fault of the Sestola Vidiciatico tectonic unit in the northern Apennines, which represents a field analogue for the shallow portion of subducted megathrusts as documented in modern subduction complexes. Such basal thrust incorporated sediments shortly after their deposition and was active at depths typical of the onset of seismicity in active megathrusts (temper- ature $c .150^{\circ} \mathrm{C}$ and burial depth $c .4-5 \mathrm{~km}$ ), allowing the mechanics of the shallowest portion of present-day megathrusts above the transition to the seismogenic zone to be discussed.

Bortolotti et al. studied blocks within the Ankara Mélange (northern Turkey), proposing that the coexistence of chemically different rock types, with ages ranging from Middle Jurassic to Early Cretaceous, is due to the melting of an highly heterogeneous mantle. Such mantle was characterized by ocean-island basalt (OIB) metasomatized portions, inherited from Triassic mantle plume activity during the continental rift and opening of the Neotethys.

\section{Regional geodynamics}

Investigations of the regional dynamics of key areas are supported by integration of field observation, sedimentary basin analysis and large-scale tectonics.

Arragoni $\boldsymbol{e t}$ al. analyse the sedimentary features of conglomerates in the southern Apennines and the composition of their acid magmatic Hercynian clasts; they infer that part of the southern Apennines represents a portion of the European palaeo-margin of the Tethys, deformed during a first Oligocene tectonic phase and, since Tortonian time, detached and transported eastwards during the opening of the Thyrrenian Sea to its present-day position.

Pandeli et al. describe their regional study of central-northern Anatolia, defining the relationships of different units affected by two metamorphic cycles (Cimmerian and Alpine) and juxtaposed in a nappe stack during syn- to late-collisional backthrusting and obduction. During this tectonic phase, sedimentary rocks of different ages were associated with ophiolitic mélange and various metamorphic rocks. Involved in a prism, some experienced blueschistfacies metamorphic imprint whereas others witnessed greenschist- to amphibolite-facies conditions.

Finally Catalano et al. (b) propose a new kinematic picture of central Sicily, focusing on the tectonic boundaries of the Caltanissetta Basin and its evolution during late Tortonian - Quaternary time. They highlight the major role of the E-W-aligned trend in the tectonic inversion of the external portions of the African palaeo-margin in Sicily, within the framework of the recent geodynamic evolution of the southern Mediterranean region.

\section{Concluding remarks}

A wide range of methods have been used by the authors in order to investigate different structural levels, from geophysics and geophysical modelling to field studies and structural geology, from microchemical analyses to the study of sedimentary systems, and from petrology to numerical modelling. The papers in this Special Issue demonstrate the importance of integrating different disciplines and methodologies to extend knowledge of complex orogenic systems, as well as 
integrating knowledge of different structural levels to achieve an improved understanding of rifting, subduction and exhumation systems through time.

Acknowledgements. This Special Issue contains 14 papers derived from the research developed in the framework of the GEOPROB project 'Birth and death of oceanic basins: geodynamic processes from rifting to continental collision in Mediterranean and circum-Mediterranean orogens', a PRIN project funded for the period 2013-2016 by the Italian MIUR (Ministero dell'Istruzione, dell'Università e della Ricerca, https://sites.google.com/site/geoprobproject/). We are very grateful for the major contribution to this Special Issue made by the reviewers.

\section{Reference}

Festa, A., Ogata, K., Pini, G. A., Dilek, Y. \& Alonso, J. L. 2016. Origin and significance of olistrostomes in orogenic belts: a global synthesis. Gondwana Research 39, 180-203. 